V. N. Bobkov, O. V. Veredyuk

\title{
IMPACT OF EMPLOYMENT INSTABILITY ON SOCIO-ECONOMIC POSITION OF EMPLOYEES
}

The subject of the article is the relationships in labor utilization.

The article analyzes the impact of employment instability on the socio-economic situation of employees in Russia. Questions revealing the concept content of employment instability, its real forms and socio-economic consequences for employees are considered. Methods of statistical and sociological data analysis are applied. Indicators to measure the scope and level of employment instability of employees are calculated. The dynamics in the time of the size of employment instability in Russia are analyzed.

The obtained results can be applied within national economic and social policy.

The findings indicate that employment instability is high, and it threatens socio-economic position of the great number of employees in Russia. It is argued that, in these conditions, the most appropriate in the fight against the spread of employment instability are the set of government initiatives, proactive position of the Russian society and the expansion of societal forms of control over the government.

Keywords: employment, labor market, sustainability, instability, precarity, employees, Russia 


\section{Introduction and Research Methodology}

Problems of sustainable development at different levels and in different segments of the socio-economic systems are at the center of political attention and research interest.

Sustainable development as a concept and goal of development acquired international recognition after the publication in 1987 of the report of the World Commission on Environment and Development, "Our Common Future.” In general, sustainable development is treated as a development that meets the needs of the present without compromising the ability of future generations to meet their own needs. The «pillars» of sustainable development are economic, social and environmental. The importance of sustainability was later confirmed at the UN Conference on Environment and Development in 1992 [1], the World Summit on Sustainable Development in 2002 [2], the World Forum on Sustainable Development, Rio +20 in Brazil in 2012 [3] etc.

Theory of socio-economic systems sustainability is still under development, overcoming many controversial issues. Though, it is accepted that these systems have internal ability to develop. Development is seen as irreversible qualitative changes accompanied, as a rule, by quantitative transformations [4, p. 192]. There are different approaches to interpretations of sustainable development in the scientific literature, as stability and balance, stability of living standards' improvement, the ability to sustain limited resources.

Development becomes unsustainable when the system moves to a new qualitative state, followed by the accumulation of antagonistic contradictions in it, or its destruction. Instability can be also interpreted as the instability of the system, its imbalances, and limitations on resources' reproduction.

The article deals with social and labor relations, in particular, employment relations as one of the main subsystem of the socio-economic system. Full and productive employment, decent work for all are recognized as the important elements of sustainable development, economic growth, social cohesion and poverty eradication, taking a central place in the international and national politics $[5]^{1}$.

The article contributes to the understanding of the changes taking place in the social-labor relations in the context of the search for answers to such questions as: do these changes provide the reproduction of human resources in the sphere

\footnotetext{
${ }^{1}$ Social and labor issues were on the agenda during the G20 summit in St. Petersburg, 5-6 September 2013.
}

of their use; do they contribute to the balance of social, economic and environmental interests of their participants; do they increase the quality of economic growth?

The changes affecting the processes and institutions of employment can be characterized as radical. Here are just some directions of these changes: labor flow from production to service sectors; the prevalence of non-materialized labor over materialized; the substitution of standard forms of employment for more flexible non-standard ones; the spread of business-networking enterprise [6] and so on.

The changes in employment can be interpreted both as positive and negative. As the positive, they usually consider the spread of employment forms, which meet the needs of a large group of actors on the labor market (women with children, the disabled, pensioners, students and etc); the faster and less costly for employer's adaptability to changes of the business environment and etc.

As the negative changes in employment, the following are seen: reduction of social security and labor rights corrosion; expansion of informal employment; weakening of trade unions' role in social and labor negotiations ${ }^{2}$; the growth of population differentiation by labor income; higher level of the youth unemployment; the existence of the working poor segment; mismatches between education and the labor market requirements and so on.

These issues for the employee may reveal as the following:

- labor contract is not properly settled;

- fixed-term contract is signed unreasonably instead of permanent ${ }^{3}$;

- wages down or delayed in time; wage level fluctuates;

- social benefits (like sick leave payments, maternity leave, workplace injuries, etc) are not provided;

- the scope of unsatisfactory working conditions expands;

- unpaid administrative leave placement;

- overtime work is not paid;

- there is no idea who the real employer is, etc.

In view of the fact that in 2012 of 71,545 million employed in the economy $93 \%$ were employees [8, p. 67], the scale of probable negative impact from social transformation of labor relations is potentially large.

\footnotetext{
${ }^{2}$ Trade unions were among the first to attract public awareness in Russia to the problem of employment precarity [7].

${ }^{3}$ For example, as unreasonable "chain contract" can be treated, when a fixed-term contract regularly prolongs.
} 
As a special term, reflecting the negative changes in the employment relations, the term "employment precarity" is used. Employment precarity forms the ground for social inequality, lost of life perspectives for a part of society, conflicts and other things, which are characterized as general precarity of life and work of individual and society as a whole.

Throughout history employment has always been precarious to one degree or another [11, p. 5]. It is now reasonable to speak about a new round, new forms and anxiety scales of employment precarity manifestations. Recently, published a special issue of the International Journal of Labour Research, ILO addressed this problem [11].

The research hypothesis is to test the claim that the scope of employment instability is increasingly threatening socio-economic position of all types of employees [11, p. 14].

\section{Concept and Socio-economic Consequences of Employment Instability of Employees ${ }^{2}$}

The "employment precarity" can be interpreted basically in two ways. Firstly, as relationships in which previously achieved social rights and guarantees of employees are reduced or absent ${ }^{3}$. Here, a wide range of rights and protections is considered, including pension rights, maternity, parental and sick leaves payments, payment for overtime work, equal pay for equal work, safe working conditions, trade unions membership; paid annual leave, etc. [11, p. 16].

Secondly, in broad interpretation, employment precarity can be seen as a system of labor relations, limiting the reproduction of the labor force. In this sense, it can be characterized as the antithesis of the Decent Work concept, developed by the ILO ${ }^{4}$.

\footnotetext{
1 Latin term "precari" (English equivalent "granted to entreaty") means "total dependence on the will of the other" [9]. According to some opinions, it became widely used after the political debates in France in the late 1970s and initially was applied to characterize social phenomenon connected with poverty $[10$, p. 342$]$.

${ }^{2}$ For more on the concept of employment instability, please see [12].

${ }^{3}$ In some official Russian translations of the ILO documents as equivalent to "precarious employment" "unprotected employment" is used [14].

${ }^{4}$ ILO defines decent work is a productive work that delivers fair income; provides security in the workplace and social protection for workers and their families; offers better prospects for personal development and encourages social integration; gives people the freedom to express their concerns, to organize and to participate in decisions that affect their lives; and guarantees equal opportunities and equal treatment for all [13, p. vi]. Although, the opposite of decent is indecent or obscene work $[15$, p. 14].
}

Employment precarity for the employee is expressed in the following: a) involuntary part-time work (even in the formal economy), b) total or partial dismantling of the "standard" employment contract $^{5}$, c) the lack of certainty or irregularity of hours of work, d) exposure to unjustified dismissal, and e) non-standard forms of employment relations. As prime examples of the latter are [11, p. 25]:

- agency work and other forms of outsourced or indirect, third party ("triangular") relationships, which obscure the relationship with the real employer;

- bogus self-employment as "independent contractors";

- abusive "apprenticeships", "internships" and "training" schemes;

- the transformation of employment contract into a commercial one (through, for example, the creation of "cooperatives");

- direct "temporary" contract (which can become "permanently" temporary), "seasonal" contract (which can flourish year round), etc.

Employment instability for the employee is usually accompanied by a loss of wages and social guarantees; decrease of social security (mainly against dismissal), mandatory social insurance and welfare payments by the employer, etc.

Thus, the employment instability includes the elements of informal and unprotected employment. And if subordination and dependence are among the basic traits / principles of employment relations of wage labor, in the case of employment instability these relations take the form of involuntary.

The above-mentioned characteristics of employment instability can be summed up under the approach proposed by the International Labour Organization, ILO. According to it, the employment instability offered viewed through the prism of the two categories of contractual agreements, which are characterized by four unstable working conditions [15, p. 29]. Significant contractual arrangements proposed are:

\footnotetext{
5 "Standard" employment contract is a contract that supports "standard" employment relationship i.e. direct relations of unlimited duration with a single employer under a full-time work, and protected against unjustified dismissal. Non-standard employment contract is a contract with limited terms; it gives the employer an additional ground for employee dismissal and, as a rule, deprives an employee of 1) receiving wage allowances and supplements linked to the seniority, 2) trade union membership and the corresponding protection, and 3) compensating for dismissal, etc. One can find a term describing the forced transition away from the standard employment relationship, "detypification", see $[6$, p. 8.]
} 
I. The limited duration of the contract (fixedterm, short-term, temporary, seasonal, day-labour and casual labour).

II. The nature of the employment relationship (triangular and disguised employment relationships, bogus self-employment, subcontracting and agency contracts).

Precarious conditions:

i. Low wage;

ii. Poor protection from termination of employment;

iii. Lack of access to social protection and benefits usually associated with full-time standard employment;

iv. Lack of or limited access of workers to exercise their rights at work.

The advantage of this approach is that it reflects not only economic but also social and humanistic framework of the employee employment relationship. It means that the changes should not lead to the reduction of the achieved social standards of employment and the living standards of households with an employee as a member.

Thus, to study the phenomenon of employment instability, in fact, means to analyze the real deviations from the employment relationship standard relevant to the achieved level of economic development ${ }^{1}$.

The growing importance of the study of employment instability is precisely because of its mid- and long-term socio-economic impact on both the employee and economy and society as a whole.

For example, in a situation of employment instability, vulnerability of the employee increases. He or she is deprived of a range of social guarantees and may face social exclusion ${ }^{2}$.

Private households with an employee as a member, who finds himself or herself in a situation of employment instability, may face the reduction mid-and long-term planning capacity in respect to a creation of a family, birth and education of children, the purchase / construction of real estate, investments in health, etc. It can happen because of the uncertain duration of employment relationships, labor income volatility, and etc.

The spread of employment instability may lead to stronger segmentation of the labor market with the protected and unprotected segments of employment. Employment characteristics within the

\footnotetext{
${ }^{1}$ The specific features of employment instability forms in different socio-economic systems, economies are mentioned in many publications, for example [11].

${ }^{2}$ The research has found that, within four years, much of the perceived "benefit" of precarity employment dissipates [15, p. 36].
}

unprotected segment are the following: low wages; lack of social security (in particular, a higher risk of dismissal); uncertain career prospects; reduced social benefits (e.g., medical treatment and education on the employer expenses).

As a consequence of employee exclusion from the social security system the overall stability of the social security system, based on the mass financial participation, is undermined. Diffusion of employment instability also results in a reduction of the respective tax revenues, eroding, as a result, the financial capabilities of the economy.

Employment instability breaks down social cohesion and has a negative impact on the development sustainability of the whole society, which can be seen in, for example:

- reduced consumer demand for products that require long-term financial resources (purchase of apartments, houses, villas, cars, etc.);

- underinvestment in human capital (education, health);

- reduced opportunities to accumulate experience and improve professional competence;

- limited availability of credit (including mortgage) and etc. Employment instability creates not just a crisis of employment quality, but also a crisis of social relations reproduction [16, p. 389].

Thus, employment instability reveals the highest degree of insecurity, involuntary economic and social instability and determines the deterioration in living standards of employees, households and the whole society.

Employment instability will be viewed as a complex socio-economic phenomenon in which level and distribution structure of the labor relations' deterioration risk in the field of employment increase and employment sphere itself ceases to be a source of effective reproduction of the labor force.

\section{Indicators and Impact Assessment of Employment Instability on Socio-economic Position of Employees}

Considering employment instability as a complex problem requires a systematic approach, including the development of indicators. In this case, the indicators should let to assess not only quantitative, but also qualitative aspects of transformations in the use of labor. In other words, indicators should reflect a degree of humanization or dehumanization of the employment relationship.

Current transformations make it difficult not only to identify the employment relationship as such [6], but also even to assess their state. According to some experts, the growth in employment instability is obvious, but official statistics 
Forms and Indicator Groups of Employment Instability of Employees

\begin{tabular}{|c|l|l|}
\hline № & Forms (aspects) of employment instability & \multicolumn{1}{|c|}{ Characteristic of indicators' groups } \\
\hline 1 & Non-standard type of labor contract & $\begin{array}{l}\text { Deviation from permanent type of labor contract standard. } \\
\text { Contract of employment that allows the employer to terminate the contract } \\
\text { at short notice and/or at will }\end{array}$ \\
\hline 2 & Informal employment & $\begin{array}{l}\text { Employment in informal (non-corporate) sector or on informal work places } \\
\text { in formal sector. The absence of formal labor agreement }\end{array}$ \\
\hline 3 & Employment instability & Frequent changes of place of work, profession \\
\hline 4 & Irregularity of employment & Extended periods out of work \\
\hline 6 & Non-standard form of employment & Deviation from standard form of labor relations; flexibility of labor relations \\
\hline 7 & Insecure employment & Deviation from normal (legally settled) duration of working time \\
\hline 8 & Involuntary form of employment & High risk (probability) of job loss \\
\hline 9 & Inadequate level of wages & Deviation from desired duration of working time \\
\hline 10 & Wage volatility & Deviation from average level of wages \\
\hline 11 & Wage discreteness & Deviation in wage amount from that agreed in labor contract \\
\hline 12 & Social vulnerability / Social exclusion & $\begin{array}{l}\text { Deviation in frequency of wage payments from that legally settled } \\
\text { ployment / Changes in the opportunities to influence decisions made by } \\
\text { others but relevant to the employee well-being }\end{array}$ \\
\hline 13 & $\begin{array}{l}\text { Mid- and long-term planning and invest- } \\
\text { ment limitations }\end{array}$ & $\begin{array}{l}\text { Deviation in volume and structure of employee and his or her family } \\
\text { investments }\end{array}$ \\
\hline 14 & Unsatisfied work environment & $\begin{array}{l}\text { Deviation from safe and healthful working conditions; state of the nature } \\
\text { environment }\end{array}$ \\
\hline 15 & Dissatisfaction with work & \begin{tabular}{l} 
Deviation from individual expectations about different aspects of work \\
\hline
\end{tabular} \\
\hline
\end{tabular}

Composed by the authors based on: $[10,11,15,17,18,19,21,22]$.

* not considered in the article.

${ }^{* *}$ It is usual when a form of employment is used as proxy of employment sustainability; see for example [15]. The examples of non-standard forms of employment are given above in the article.

under-report the extent of the phenomenon [11, p. 29].

Employment instability is a multidimensional phenomenon. In this regard, it follows that it should be measured by a system of indicators. Table 1 represents the systematized real forms (aspects) of employment instability of employees and suggests characteristic of the respective groups of indicators. It is believed that these groups of indicators should help to give, if not comprehensive, then at least the diversified assessment of the level and scope of employment instability of employees.

The level and scope of employment instability analyzed below (through the analysis of deviations from the achieved employment standards) are relevant to the formal sector of the Russian economy. The informal sector with the bulk scale of unregistered employment and the most acute forms of employment instability is not considered in the article ${ }^{1}$.

The main statistical database to assess the impact of employment instability on socio-economic

\footnotetext{
${ }^{1}$ About most acute forms of employment instability in Russia, see for example, [12, p. 46-47].
}

position of employees in Russia used in the article was the Russian Longitudinal Monitoring Survey (RLMS-HSE) [20] (hereinafter - the Monitoring). In particular, estimations were made on data of representative individual panel of round 20th of the Monitoring collected from October 2011 to February 2012 (totally 17,024 observations).

The assessment of employment instability impact on socio-economic position of employees in Russia is based on an analysis of a number of indicators derived from the Monitoring database (see Table 2), corresponding to the real forms (aspects) of employment instability of employees (see Table 1$)^{2}$.

According to the International Classification of Status in Employment, ICSE-93, employees are those workers who hold the type of job defined as "paid employment jobs", i.e. jobs where the incumbents hold explicit (written or oral) or implicit employment contracts, which give them a basic remuneration that is not directly depend-

\footnotetext{
2 When possible, to see the dynamics (during 10 years period) in different forms (aspects) of employment instability development, relative statistic from the earlier Monitoring (round 11 of the year 2002) is provided (hereinafter - the Monitoring 2002).
} 


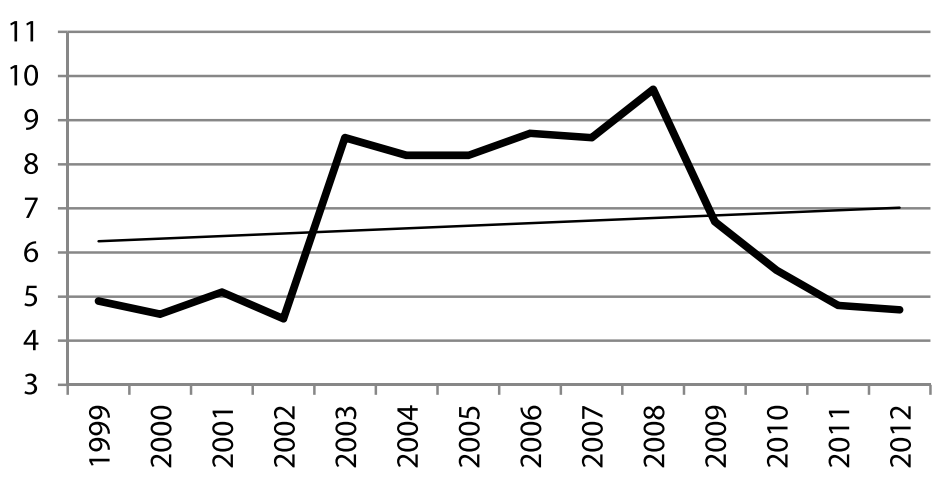

Fig. Non-standard Labor Contract Spread Dynamic in Russia (in Percentage of

Total Number of Employees) (Estimations are based on [8, p. 71;23, p. 63])

second this duration was more than 1.5 times higher than normal (it is more than in 2002). At the same time, insufficient duration of working week was for $8 \%$ of the employees (it is less than in 2002).

Inadequately low level of wages. The Monitoring data show that almost half $(48 \%)$ of the employees received wages below two thirds of the average in the economy (it is higher than in $2002)^{4}$. According to the ILO, low wages are those which are less than two thirds

ent upon the revenue of the unit for which they work [21]. Following this approach, into a group of employees we included those who recognized themselves as currently working in the legal entity or organization, and at the same time not neither had entrepreneurial activity nor were owners or shareholders. From total 6,936 employees, ${ }^{1}$ $93 \%$ were employed formally (i.e. under legal labor contract), and $6 \%$ were without legal contract (in $72 \%$ of cases it was forced from the employer). Over ten years (from 2002 to 2012) a share of employees not officially employed grew.

Unfortunately, the Monitoring does not allow to identify other groups of employees by type of contract - one of the key real forms of employment instability. However, according to official statistics, under "non-standard" contract in $20124.7 \%$ of the employees worked in Russia ${ }^{2}$. Figure represents the dynamic in the spread of non-standard contracts from 1999 to 2012 among the employees.

Since the late 1990s, despite the prevalence of permanent employment contract, there has been a general trend to replace it by "non-standard" types of contract. The highest share they gained during the crisis year of 2008, when under "non-standard" $10 \%$ of the employees worked.

During 12 months employment instability characterized $16 \%$ (19\% in 2002) of the employees who either changed their place of work and/ or their profession.

The duration of working week ${ }^{3}$ exceeded the norm for $15 \%$ of the employees, of which for every

\footnotetext{
${ }^{1}$ When analyzing the Monitoring only definite answers like "yes" and "no" were considered.

${ }^{2}$ Estimations are based on the official aggregated statistics of the employees who work under a fixed-term contract (which ends by the rule of a specific date or the end of a task). Oral contract is not included [8, p. 71].

${ }^{3}$ ILO considers as excessive working time hours of work, which exceed 48 hours per week [26]. In Russia, the standard (normal) duration of work is 40 hours per week [17, cl. 91]. Thus for Russia, excessive working time is more than $120 \%$ of the stand-
} of the median hourly earnings [22]. It is difficult to be accurate calculating the level of hourly earnings on the Monitoring data. So, we address here to official statists showing that such wages were paid to $30 \%$ of the employees in Russia. It demonstrates also that it is more probable for women to find themselves in such situation than for men: $37 \%$ and $20 \%$ respectively [18].

Inadequately low level of wages is confirmed from the Monitoring by the fact that $12 \%$ of the employees take credits to meet current consumption!

During 12 months wage volatility followed by its discreteness of wage payments (in form of wage cuts because of involuntary reduced hours of work or/and unpaid leave) was experienced by minimum $5 \%$ of the employees (in $2002-7 \%$ ), of which every second experienced both.

The analyzed round of the Monitoring does not contain the whole block of questions applicable to assess the level of social vulnerability of the employees. According to the previous 19th round of the Monitoring, ${ }^{5}$ sick leave was paid for $87 \%$, the medical treatment - for $20 \%$ and vocational training - for $21 \%$ of the employees.

However, we can assess the level of social vulnerability analyzing the results of two "ladders of well being" with nine stairs each. In the first case, on the lowest stair there are those who feel themselves as being the poor, and at the top - as the rich. In the second case, on the lowest stair there are those who feel powerless and at the top those who believe that they have a lot of power. We got the following results: in the first case, $57 \%$ (in 2002-68\%) of the employees classified themselves as a group with well-being below the av-

ard (i.e. more than 48 hours per week) and insufficient working time - less than $80 \%$ (i.e. less than 32 hours per week).

${ }^{4}$ Estimations are based on the average nominal gross wages of the employees in organizations in $2011-23369 \mathrm{rub}$ [24] and in $2002-4360 \mathrm{rub}$ [25].

${ }^{5}$ Round 19th of the Monitoring collected from October 2010 to March 2011 (totally 16,867 observations). 
Summary Evaluation of Employment Instability Dynamics of Formal Sector Employees in Russia

\begin{tabular}{|c|c|c|c|}
\hline \multirow[t]{2}{*}{ Indicator of employment instability } & \multirow{2}{*}{$\begin{array}{l}\text { Employment insta- } \\
\text { bility form number } \\
\text { (from table 1) }\end{array}$} & \multicolumn{2}{|c|}{$\begin{array}{l}\text { Share of employees in total } \\
\text { number of employees (\%) }\end{array}$} \\
\hline & & 2002 & 2012 \\
\hline $\begin{array}{l}\text { Zero mid- and long-term investment (in real estate) of an employee and } \\
\text { his/her family }\end{array}$ & 13 & 87 & 84 \\
\hline $\begin{array}{l}\text { Low level social guarantees and rights (the lowest stairs of "well being } \\
\text { ladders") }\end{array}$ & 12 & 70 & 60 \\
\hline High risk assessment of job loss & 7 & 52 & 56 \\
\hline Wage is below $2 / 3$ of the average for an economy & 9 & 40 & 48 \\
\hline Dissatisfaction with work on the whole & 15 & 31 & 14 \\
\hline Changes of place of work and/ or profession during 12 months & 4 & 19 & 16 \\
\hline Excessive duration of working week (more than 48 hours) & 6 & 17 & $15^{*}$ \\
\hline Involuntary wage reduction and involuntary reduction of working hours & 10 & 7 & 5 \\
\hline Employment under a fixed-term formal contract ${ }^{* *}$ & 1 & 4 & 5 \\
\hline Legal labor contract is absent & 2 & 4 & 6 \\
\hline
\end{tabular}

Estimations are based on the RLMS rounds 11 and 20 [20].

* Although, the share of employees within this group whose hours of work on average exceeded the norm (40 hours per week) by 1.5 time and more increased.

${ }^{* *}$ Estimations are based on $[8,23]$.

erage level, in the second case - $62 \%$ (in $2002-$ $72 \%$ ) of the employees keenly (above the average) feel their powerlessness.

Mid- and long-term planning and investment limitations. The Monitoring analysis estimates employees' opportunities to invest if they wish to. There zero opportunities: to improve living conditions (to buy a room, apartment or house) are for $90 \%$ of the employees ( $91 \%$ in 2002); to save money for a major purchase (a car, cottage) for $77 \%$ (83\% in 2002), and to finance abroad family holiday - for $80 \%$ of the employees.

Among those employees who faced a problem of extra-classes for children (school of music, foreign languages, sports clubs, etc.) $32 \%$ could not afford these payments. This percentage was even greater (up to $53 \%$ ) in case of a high school education.

As for unsatisfied work environment, for $14 \%$ of the employees working conditions were such that they gave them right for early retirement, additional payments and benefits.

High (above the average) level of dissatisfaction with work on the whole experienced $14 \%$ of the employees (compared to $31 \%$ in 2002). While, more than half of this number (55\%) expressed high (above the average) concern about the risk to lose a job. It should be stressed that the assessment of the risk of job loss (both among the satisfied and dissatisfied by the work groups of employees) during the concerned period of ten years increased.

The above analyzed major indicators introduced to monitor and evaluate the deviations from the employment relationship standard (i.e. differ- ent forms of employment instability) are combined in table 2 by influence scope on employees.

Assuming the specificity of employment instability forms for employees in Russia, we defined as the main the following forms with corresponded indicators:

1) informal employment (when legal labor contract is absent);

2) inadequate level of wages (wages below two thirds of the average for the economy) and social vulnerability and social exclusion (the lowest stairs of "well being ladders");

3) mid- and long-term planning and investment limitations (zero mid- and long-term investment (in real estate) capacity of an employee and his/her family). These forms and corresponded indicators were used for classification into three groups the employees in the situation of employment instability in Russia.

The first group of employees is with the highest level of employment instability. It is about $6 \%$ of the employees working in the formal sector without legal employment contract. They form the core of precarity in the formal sector. Here, we have an example of informal employment forms in the formal sector.

The second group of employees is with high employment instability has the major share. The share of employees with inadequate level of wages (wages below two thirds of the average for the economy) and social vulnerability (the lowest stairs of "well being ladders") equals from $50 \%$ to $60 \%$ of total the number of employees. This group of employees often faces such forms of employment instability as non-standard duration of 
working time, non-standard type of labor contract, employment instability and insecurity.

The peripheral forms of employment instability characterize the third group of employees. It covers up to $85 \%$ of employees with mid- and long-term planning and investment limitations (equal 0) for an employee and his/her family. The scope of this group is a signal of high degree of employment instability of the Russian society.

\section{Conclusion}

The results obtained on the RLMS-HSE data, and other sources, confirm the tested hypothesis that the scope of employment instability is high ${ }^{1}$ and it threatens socio-economic position of the great number of employees in Russia.

All the suggested forms (aspects) of employment instability were identified in Russia ${ }^{2}$. As a result, three groups of employees were classified according to a degree of employment instability: 1) the group with the highest level of employment

\footnotetext{
${ }^{1}$ In the group of employees not affected by the employment instability (i.e. none of the forms was distinguished) were only $0.6 \%$.

${ }^{2}$ Except two (Irregularity and Involuntary form of employment) which were not analyzed at all.
}

instability; 2) the group with high employment instability, and 3) the group with peripheral forms of employment instability. Thus, the level of employment instability depends on the group and varies in Russia from 6\% to $85 \%$.

Some estimated indicators of employment instability demonstrated the downward (negative trend) of employment standards in Russia. At the same time, other indicators during the considered period of ten years remained high, illustrating not only the large scope of employment instability, but also its chronic nature.

Employment instability can be put in a broader context of searching for a new balance between economic and social components of modern globalized processes that are equivalent to searching for a new employment model. This is extremely important because today as a tool to decrease tension of employment instability, it is proposed to reduce (!) social guarantees [11, p. 14]. The authors cannot support this position.

Employment instability requires systematic, mainly government, efforts to address all aspects of its specific nature [11, p. 16], along with proactive position of the Russian society and the expansion of societal forms of control over the government.

\section{Reference}

1. United Nations. (1992). Rio Declaration on Environment and Development. The United Nations Conference on Environment and Development in Rio de Janeiro from 3 to 14 June 1992. Available at: http://www.un.org/documents/ga/conf151/ aconf15126-1annex1.htm (date of access: 15.08.2013).

2. United Nations. (2002). The World Summit on Sustainable Development in Johannesburg. Declaration on Sustainable Development in South Africa, from 26 August to 4 September 2002. Available at: http://www.un.org/jsummit/html/documents/ summit_docs/131302_wssd_report_reissued.pdf (date of access: 15.08.2013).

3. United Nations. The United Nations Conference on Sustainable Development in Rio de Janeiro from 20 to 22 June 2012. "Future We Want." Available at: http://sustainabledevelopment.un.org/futurewewant.html

4. Uskova T. (2012). Ustoychivoye razvitie i ekonomicheskiy rost: teoretiko-metodologicheskie podkhody $\mathrm{k}$ opredeleniyu [Sustainable Development and Economic Growth: Theoretical and Methodological Approaches to Definition]. Materials of the Conference "Economic Growth, Resource Dependence and Socio-economic Inequity," 22-24 October 2012. St. Petersburg, NestorHistory Publ.

5. United Nations. (2012). The Millennium Development Goals Report 2012. New York, NY: United Nations. Available at: http://www.un.org/millenniumgoals/pdf/MDG\%20Report\%202012.pdf (date of access: 15.08.2013).

6. Renato Bignami, Giuseppe Casale, Mario Fasani. (2013). Labour inspection and the employment relationship. International Labour Office, Labour Administration and Inspection Programme (LAB/ADMIN). Geneva: ILO, 78.

7. Starostin V. (2008). Razmyshlenie o prekarizatsii v rudovykh otnosheniyakh [Thoughts on Precarity in Labour Relations]. Available at: http://sibokt.livejournal.com/4011.html (date of access: 07.01.2013).

8. ROSSTAT. (2013). Ekonomicheskaya aktivnost naseleniya Rossii [Economic Activity of the Population 2012]. Moscow, Rosstat. Available at:

9. URL: http://www.dict.org/bin/Dict (date of access: 10.08.2012).

10. Prekarisierung und Flexibilisierung (Precarity and Flexibilisation). (2012). Rolf-Dieter Hepp, WESTFALISCHES DAMPFBOOT.

11. Meeting the challenge of precarious work: A workers' agenda. (2013). International Journal of Labour Research. ILO, Geneva, 5, 1 .

12. Bobkov V., Veredyuk O. (2013). Neustoychivost zanyatosti kak sovremennaya problema I issledovatelskaya kategoriya [Precarity of Employment as a Problem and Scientific Category]. Uroven zhini naseleniya regionov Rossii [Standards of Life of Region's Population in Russia], 6, 43-51.

13. ILO. (2007). Toolkit for mainstreaming employment and decent work. United Nations System Chief Executives Board for Coordination Geneva, International Labour Office, Available at: http://www.ilo.org/wcmsp5/groups/public/---dgreports/---exrel/ documents/publication/wcms_172609.pdf (date of access: 02.09.2013). 
14. ILO. (2009). Izmereniye dostoynogo truda na osnove rekomendatsii Tryokhstoronnego soveshchaniya ekspertov po izmereniyu dostoynogo truda [Revised Office proposal for the measurement of decent work — indicators]. Available at: http:// www.ilo.org/wcmsp5/groups/public/---dgreports/---integration/documents/meetingdocument/wcms_192844.pdf (date of access: 02.09.2013).

15. ILO. (2012). From precarious work to decent work: outcome document to the workers' symposium on policies and regulations to combat precarious employment. International Labour Office, Bureau for Workers' Activities. - Geneva, 86. Available at: http://www.ilo.org/wcmsp5/groups/public/---ed_dialogue/---actrav/documents/meetingdocument/wcms_179787.pdf (date of access: 07.05.2013).

16. Lee C. K., Kofman Y. (2012). The Politics of Precarity: Views Beyond the United States. Work and Occupations, 39 (4), $388-$ 408.

17. Labor Code of the Russian Federation (with amendments from 23.07.2013).

18. ROSSTAT. Indikatory dostoynogo truda [Decent Work Indicators]. Available at: http://www.gks.ru/wps/wcm/connect/ rosstat_main/rosstat/ru/statistics/wages/ (date of access: 01.09.2013).

19. ILO. Final report of the 17th International Conference of Labour Statisticians. Available at: http://www.ilo.org/wcmsp5/ groups/public/---dgreports/---stat/documents/meetingdocument/wcms_087568.pdf (date of access: 05.09.2013).

20. "Russia Longitudinal Monitoring survey, RLMS-HSE," conducted by the National Research University Higher School of Economics and ZAO "Demoscope" together with Carolina Population Center, University of North Carolina at Chapel Hill and the Institute of Sociology RAS. Available at: (http://www.hse.ru/rlms, http://www.cpc.unc.edu/projects/rlms)

21. Resolution concerning the International Classification of Status in Employment (ICSE), adopted by the Fifteenth International Conference of Labour Statisticians (January 1993). Available at: http://www.ilo.org/wcmsp5/groups/public/---dgreports/---stat/documents/normativeinstrument/wcms_087562.pdf (date of access: 05.09.2013).

22. ILO. (2012). Decent work indicators: concepts and definitions: ILO manual. International Labour Office. First edition, Geneva: ILO, 175. Available at: http://www.ilo.org/wcmsp5/groups/public/---dgreports/---stat/documents/publication/ wcms_183859.pdf (date of access: 07.09.2013).

23. ROSSTAT. (2006). Ekonomicheskaya aktivnost naseleniya Rossii 2006 [Economic Activity of the Population 2012]. Moscow, Rosstat.

24. ROSSTAT. (2012). Rossiyskiy statisticheskiy ezhegodnik [Russian Statistical Yearbook]. Moscow, Rosstat. Available at: http://www.gks.ru/bgd/regl/b12_13/IssWWW.exe/Stg/d1/06-09.htm (date of access: 07.09.2013).

25. ROSSTAT. (2007). Rossiyskiy statisticheskiy ezhegodnik [Russian Statistical Yearbook]. Moscow, Rosstat. Available at: http://www.gks.ru/bgd/regl/b07_13/IssWWW.exe/Stg/d02/06-09.htm (date of access: 07.09.2013).

\section{Information about the authors}

Vyacheslav N. Bobkov (Moscow, Russia) - Doctor of Economics, Professor, General Director, PJSC "All-Russian Centre of Living Standard" (29, 4th Park street, 105043, Moscow, Russia, e-mail: bobkovvn@mail.ru).

Olesya V. Veredyuk (St. Petersburg, Russia) - PhD in Economics, Associate Professor, Faculty of Economics, the St. Petersburg State University (62, Tchaykovskogo st., 191123, St. Petersburg, Russia, e-mail: o.veredyuk@econ.pu.ru). 